\title{
JOURNAL.RU
}

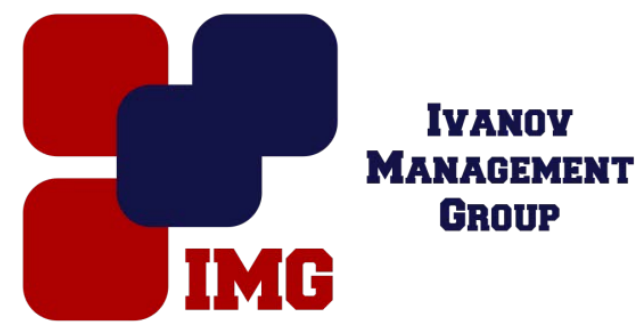

Бачурина А.С., Тихонова С.Н. детское ЛОР отделение горбольницы № 1 им. Н.А. Семашко МБУЗ детская городская поликлиника №8 Ростов-на-Дону, Россия

doi: 10.18411/lj-30-11-2016-3-01

idsp 000001:lj-30-11-2016-3-01

\section{Анализ отдаленных результатов аденотомии}

Аденоиды занимают первое место среди причин затруднения носового дыхания у детей [1], а аденотомия является наиболее распространенным хирургическим вмешательством в детской оториноларингологической практике [2]. Основными показаниями к операции являются затруднение носового дыхания, синдром обструктивного апноэ сна и патология среднего уха. Нередко аденотомия производится одновременно с тонзиллотомией или тонзиллэктомией $[3,4,5]$.

Целью нашего исследования было оценить отдаленные результаты после аденотомии и аденотонзиллотомии у детей.

Пациенты и методы исследования. Произведено анкетирование родителей 45 детей, подвергнутых хирургическому лечению по поводу аденоидов / гипертрофии лимфокольца глотки в 2013 году. В анкете предлагалось указать основные жалобы перед операцией и оценить регресс этих симптомов через 3 года после хирургического вмешательства. В случае сохранения каких-либо симптомов дети приглашались на контрольный осмотр.

Результаты. По результатам опроса было установлено, что ведущими симптомами, явившимися показаниями к операции были: затруднение носового дыхания - у 45 детей (родители 8 детей отмечали «постоянно открытый рот»); нарушение сна - (беспокойный сон, храп) у 38 детей; вялость, адинамичность, утомляемость, нарушение внимания - у 35 детей; частые ОРВИ - у 45 детей (более 4 раз в год - у 32, каждый месяц - у 13); рецидивирующие гнойные синуситы, по поводу которых выполнялись пункции верхнечелюстных пазух - у 7 ; «непроходящий насморк» - у 15; рецидивирующий острый средний отит - у 16; экссудативный отит с длительным течением - у 5; снижение слуха - у 12. 
Таблича 1

Результаты лечения через 3 года после операчии.

\begin{tabular}{|c|c|c|c|c|}
\hline \multirow[b]{2}{*}{ Симптом } & \multicolumn{2}{|c|}{ До операции } & \multicolumn{2}{|c|}{ После операции } \\
\hline & $\begin{array}{l}\text { количеств } \\
\text { о }\end{array}$ & $\%$ & $\begin{array}{l}\text { количеств } \\
\text { о }\end{array}$ & $\%$ \\
\hline затруднение носового дыхания & 45 & & 2 & \\
\hline нарушение сна (беспокойный сон, храп) & 38 & & 1 & \\
\hline частые ОРВИ & 45 & & 1 & \\
\hline $\begin{array}{l}\text { вялость, адинамичность, утомляемость, нарушение } \\
\text { внимания }\end{array}$ & 35 & & 0 & \\
\hline снижение слуха & 12 & & 4 & \\
\hline рецидивирующие гнойные синуситы & 7 & & 0 & \\
\hline «непроходящий насморк» & 15 & & 0 & \\
\hline отсутствие жалоб & 0 & & 33 & \\
\hline
\end{tabular}

При оценке отдаленных результатов хирургического вмешательства отмечено полное отсутствие жалоб у 33 детей.

Вялость, адинамичность, утомляемость, нарушение внимания перестали беспокоить всех прооперированных пациентов.

У 8 из 12 детей, имевших до операции пониженный слух, пороги слухового восприятия восстановились до физиологической нормы, у 4 - слух оставался сниженным, имелись дополнительные жалобы и симптомы: у одного искривление перегородки носа с нарушением дыхания, у второго рецидивирующий острый средний отит.

У 1 ребенка сохранились признаки синдрома ночного апноэ сна, однако, у этого пациента можно предполагать его центральное происхождение ввиду наличия неврологической патологии.

Из 45 прооперированных 1 пациент стал часто болеть бронхитами вместо частых ОРВИ.

Рецидивирующие гнойные синуситы беспокоят 2 пациентов, но частота обострений их значительно уменьшилась. Кроме того, в свете современных представлений о роли иммунной системы в формировании хронического риносинусита $[6,7,8]$, этим детям было рекомендовано обследование и лечение у иммунолога. Четырем детям с измененным лицевым скелетом и с сформировавшимся неправильным прикусом была назначена консультация ортодонта. 


\section{Литература}

1. Бойко Н.В., Колесников В.Н., Левченко Е.В. Статистика причин затруднения носового дыхания. Рос ринология. 2007. № 2. С. 24-25.

2. Бойко Н.В., Бачурина А.С. Аденотомия и аденотонзиллотомия у детей с затруднением носового дыхания. Рос. ринология. 2015. Т. 23, №1. С. 9-12.

3. Бойко Н.В., Бачурина А.С., Жданов А.И. Профилактика послеоперационных кровотечений при аденотомии. Рос. ринология. 2015. T.23, №2. С.26-30.

4. Бойко Н.В., Гукасян Е.Л., Быкова В.В. Статистика хирургических вмешательств при хроническом тонзиллите. Вест оторинолар. 2008. № 5. C. 234.

5. Бойко Н.В., Локшина Л.С., Сорока Г.Г., Бриж Ю.В., Сулина Н.Ю. Измене-ние подходов к лечению хронического тонзиллита в детском возрасте по материалам Ростовской ЛОР клиники. Вестник оторинолар. 2012; 5: 226.

6. Стагниева И.В., Симбирцев А.С. Эффективность иммуномодулирующей терапии у больных риносинуситом. Медицинская иммунология. 2015. Т. 17. № 5. С. 423-430.

7. Стагниева И.В., Симбирцев А.С. Иммуномодулирующая терапия у больных риносинуситом с латентным течением. Медицинская иммунология. 2015. Т. 17. № S. C. 423.

8. Стагниева И.В., Гукасян Е.Л., Сагакянц А.Б. Нарушение ней-роиммунной реактивности у больных риносинуситом. Российская ри-нология. 2015. Т. 23. № 1. C. 25-28. 